\title{
DARBUOTOJŲ POREIKIŲ TENKINIMAS LIETUVOS ORGANIZACIJOSE
}

\author{
Sonata Staniulienė, Inga Kurienė \\ Vytauto Didžiojo universitetas (Lietuva)
}

\begin{abstract}
Anotacija
Straipsnyje analizuojama darbuotojų poreikių tenkinimo Lietuvos organizacijose tema, remiantis A. Maslow'o poreikių hierarchijos teorija. Motyvacija vaidina svarbų vaidmenį, kad žmonès būtų sèkmingi ir laimingi tiek kasdieniame, tiek darbiniame gyvenime. Kiekvienas žmogus ieško visų įmanomų būdų, kaip patenkinti savo poreikius organizacijoje, kurioje dirba, o neįstengdamas to padaryti yra linkęs keisti mažiau patenkinamą būklę ị geresnę. Poreikių hierarchijos teorija buvo plačiai pripažinta, ją ypač palaikè vadovai praktikai, nes ji logiška ir paprasta, taigi nesunkiai suprantama. Ši teorija paaiškino, kas žmones skatina dirbti, o vadovams įrodè, kad darbo motyvus lemia platus poreikių spektras. Remiantis tyrimu, rezultatai Lietuvos organizacijose atitinka A. Maslow'o poreikių hierarchijos teoriją, kuri teigia, kad pirmiausia turi būti patenkinti žemesnès poreikių hierarchijos pakopos poreikiai, kad būtų sudarytos sąlygos patenkinti kitus.

PAGRINDINIAI ŽODŽIAI: A. Maslow’o poreikių hierarchija, fiziologiniai, saugumo, socialiniai, pagarbos, savirealizacijos poreikiai.
\end{abstract}

\begin{abstract}
The article analyses the satisfaction of employee needs in Lithuanian organisations, according to A. Maslow's theory of needs hierarchy. Motivation plays an important role in making people successful and happy in both their daily and their work life. Everyone looks for all possible ways to meet their needs in the organisation they work for, and doing so tends to change from a less satisfactory condition to a better one. The theory of the hierarchy of needs has been widely accepted, and has been particularly supported by many managers, largely because it is logical and simple, and therefore easy to understand. This theory explains what motivates people to work, and has shown managers that work motives are determined by a wide range of needs. According to the study, the results in Lithuanian organisations are in line with Maslow's theory of the hierarchy of needs, which states that the needs of the last level of the hierarchy of needs must be met first, in order to create the conditions for the next.

KEY WORDS: A. Maslow's hierarchy of needs, physiological, safety and security, belonging, esteem, self-actualisation of needs
\end{abstract}

DOI: $\underline{\text { http://dx.doi.org/10.15181/tbb.v87i2.2316 }}$

\section{Ivadas}

Išskirtinio dèmesio darbuotojui, kaip unikaliam organizacijos ištekliui, teikimas jị motyvuoja dirbti. Savo ruožtu aktyvūs organizacijos darbuotojai užtikrina iškeltų tikslų igyvendinimą, kartu patenkinami kiekvieno dirbančio žmogaus asmeniniai poreikiai. Darbuotojų poreikių tenkinimas, realizuojant asmens fiziologinius ir intelektinius gebejimus aktyvioje darbineje veikloje, suponuoja tiesiogi- 
nes sąsajas su organizacijos rezultatyvumu, kuris lemia individo, organizacijos ir visuomenès gyvavimo kokybę, tad darbuotojų motyvacijos didinimo sprendimai suvoktini per individų poreikių tenkinimo mechanizmų paiešką ir jų diegimą. Sèkmingai darbuotojus motyvuoti galima tik žinant jų poreikius. Kiekvienas individas ieško galimybių, kaip patenkinti savo poreikius organizacijoje, kurioje dirba, o neịstengdamas to padaryti yra linkęs keisti mažiau patenkinamą būklę ị geresnę - ieško galimybių įsidarbinti kitoje įmonèje arba apskritai emigruoja iš šalies (Šerikova, Matuzienè, 2006).

Mokslininkų tyrimų rezultatų analizè patvirtina numatomą teigiamą pagrindinių poreikių tenkinimo poveikį organizacijoms. Pavyzdžiui, poreikių tenkinimas susijęs su aukštesniais rezultatais (Baard, Deci, Ryan, 2004), didesniu organizaciniu ịsipareigojimu (Gagne, Chemolli, Forest, Koestner, 2008), didesniu pasitenkinimu darbu (Van den Broeck, Vansteenkiste, Lens, De Witte, 2010) ir mažesniu perdegimo dažniu (Van den Broeck, Vansteenkiste, De Witte, Lens, 2008). Pagrindinių poreikių tenkinimas siejamas su vidine motyvacija, o tai gali atsverti organizacijos taikomas darbuotojų išorinio motyvavimo priemones (Van den Broeck ir kt., 2016). Apskritai kiekvienos poreikių grupès patenkinimas panašiai veikia darbuotojų motyvaciją, daugelyje tyrimų poreikių tenkinimas nagrinėjamas kaip visuma, t. y. apima visus galimus poreikius (Van den Broeck ir kt., 2016).

A. Maslow'o poreikių hierarchijos teorija tyrëjai remiasi kaip pagrindu tirdami individų poreikius (Mahyuddin, Abdullah, 2011). Kaip pažymėjo J. Perkins'as (2004), kai kuriose pasaulio valstybėse net dirbantys individai iš gaunamo atlygio negali patenkinti savo fiziologinių poreikių. Anot A. Trethewey, H. L. Goodall'o (2007), individams organizacijose dèl spartaus ir chaotiško IT vystymosi tenka grįžti ị A. Maslow'o poreikių hierarchijos saugumo kvestionavimo pakopą. E. Fife ir F. Pereira (2008) tyrimas atskleidè, kad daugelio galutinių vartotojų gyvenime vis dar vyrauja A. Maslow'o poreikių hierarchija, daugelis jų pirmiausia rūpinasi finansiniu saugumu, sveikatos priežiūra ir švietimu. O štai J. Cangemi (2009) tyrimu Pietų Amerikoje nustatyta, kad, remiantis A. Maslow'o teorija, be pagrindinių poreikių, darbuotojai siekia patenkinti du didžiausius poreikius, kurie patenka ị pagarbos ir savirealizacijos kategorijas. V. Hing Po Lam'as (2020) tyrinėja, kaip šiuolaikiniai partnerystès su darbdaviu santykiai paveikia laisvai samdomų darbuotojų poreikių tenkinimą.

Visgi pats A. Maslow'as (1954) teigè, kad tik vienas procentas individų iš tikrųjų gali patenkinti savirealizacijos poreiki, tuo tarpu kitiems aktualesni yra pagarbos lygmens poreikiai. Atsižvelgiant ị laikmečių pokyčius, kultūrinius, socialinius ir politinius ypatumus, verta tyrinèti, kokios A. Maslow'o poreikių hierarchijos pakopos darbuotojų poreikius pavyksta patenkinti Lietuvos organizacijoms, tad 
tyrime keliama mokslinė problema - kaip tenkinami Lietuvos organizaciju darbuotojų poreikiai, remiantis A. Maslow'o poreikių hierarchijos teorija.

Tyrimo tikslas: išanalizuoti, kaip darbuotojų poreikiai tenkinami Lietuvos organizacijose.

Tyrimo metodai: mokslinès literatūros analizè, Lietuvos organizacijų darbuotojų apklausa.

\section{Tyrimo teorinis pagrindimas}

Motyvacija vaidina svarbų vaidmenį, kad žmonès būtų sèkmingi ir laimingi tiek kasdieniame, tiek darbiniame gyvenime. Būtina išlaikyti aukštą darbuotojų motyvacijos lygi siekiant teigiamai prisidèti prie darbuotojų gerovès ir organizacijų tvarumo.

Pasak D. O'Connor'o, L. Yballe (2007), psichologas A. Maslow'as, žinomas kaip humanistinio judejimo atstovas, psichologijai suteikè dvasingumo, nes individą matè kaip visumos dali. B. Soni ir R. Soni (2016) teigimu, pats A. Maslow'as daugelị vẻlesnių metų praleido aiškindamasis, kas motyvuoja save realizuojantị asmenį, t. y. tą, kuris stengiasi išnaudoti visą savo potencialą. A. Maslow'as ieškojo aukštesnių poreikiu pakopų, kurios remiasi esminėmis vertybėmis, tokiomis kaip tiesa, gèris, grožis, pažinimo siekis, supratimas, tikslingumas, tobulumas ir kompetencija, peržengiančiomis tik asmeninị asmens interesą.

Yra keletas motyvacijos teorijų, kurios sukurtos siekiant paaiškinti darbuotojų motyvacijos ir poreikių tenkinimo lygmenis (Ozsoy, 2019). Poreikių hierarchijos teorija plačiai pripažinta ir taikoma, nes yra logiška ir paprasta, taigi nesunkiai suprantama. Ši teorija paaiškino, kas žmones skatina dirbti, o vadovams įrode, kad darbo motyvus nulemia platus poreikių spektras (Vveinhardt, Gulbovaité, 2013).

A. Maslow'o poreikių hierarchijos teorija (1954) - žinomiausia ir daugiausia dèmesio sulaukusi motyvacijos teorija, grindžiama individų poreikiais (ypač susijusiais su darbu). Jis iškèlè hipotezę, kad žmones veikti skatina įvairūs poreikiai, kurie turi tam tikrą hierarchiją ir gali būti suskirstyti ị penkis lygmenis: fiziologinius, saugumo, socialinius, pagarbos ir savirealizacijos:

1. Hierarchijos apačioje yra pagrindiniai, arba fiziologiniai, poreikiai, tokie kaip maistas, vanduo, pastogè ir pan. Tik patenkinę pagrindinius mitybos poreikius, žmonės bandys siekti daugiau. A. Maslow'o nuomone, šie poreikiai yra patys svarbiausi, instinktyvūs, tuo tarpu visi kiti - antraeiliai, kol nepatenkinti šie fiziologiniai poreikiai.

2. Patenkinę fiziologinius poreikius, žmonès siekia saugumo. Saugumo poreikiai yra svarbūs norint išgyventi, vis dèlto jie ne tokie svarbūs, kaip fiziolo- 
giniai. Tai nuolatinio užimtumo, sveikatos draudimo, saugių rajonų paieškos ir prieglobsčio nuo aplinkos siekis.

3. Žmonèms svarbus priklausomybès ir meilès jausmas. A. Maslow'o nuomone, socialiniai poreikiai yra mažiau svarbūs nei fiziologiniai ir saugumo. Tokie santykiai kaip draugystė, romantiškas prisirišimas, šeima padeda patenkinti A. Maslow'o hierarchijos bendravimo ir priemimo, dalyvavimo socialinèje, bendruomeninèje ar religinèje grupèje poreikius.

4. Pagarbos poreikis kyla žmogui patenkinus savo socialinius poreikius. Šis poreikių lygmuo bus pasiektas, kai žmogus jausis gerai tai pasiekęs. Tai ir sèkmès lygmuo arba statusas, pripažinimas.

5. Savirealizacijos poreikių tenkinimas - aukščiausias A. Maslow'o poreikių hierarchijos lygmuo. Pasiekusieji šių poreikių lygmenị žino ir rūpinasi asmeniniu augimu, išnaudoja savo galimybes. Tačiau jiems mažiau rūpi kitu nuomonè.

Remiantis A. Maslow'o teorija, gyvenimo kokybė bus užtikrinta, patenkinus pagrindinius poreikius. Individui negalint patenkinti savo pagrindinių poreikių, jo gyvenimas nebus kokybiškas (Zakaria, Ahmad, Malek, 2014).

Visus poreikius A. Maslow'as suskirste ị žemesnio (fiziologinius, saugumo) ir aukštesnio (socialinius, pagarbos, saviraiškos) lygmens. Žemesnio lygmens poreikiai yra pirminiai, tad svarbesni individui nei paskesni (Lester, 2013). Remiantis A. Maslow'o teorija, kuo geriau patenkinami fiziologiniai poreikiai, tuo labiau žmogus sieks patenkinti saugumo poreikius, taigi individai, prieš svarstydami apie asmeninio saugumo poreikius, sprendimus priima pirmiausia atsižvelgdami i savo fiziologinių poreikių suvokimą. Jų iki galo nepatenkinus, galimos socialinès pasekmès, nes žmonès gali prisiminti savo nepatenkintus poreikius (Ryan ir kt., 2020). Šia poreikių struktūra siekta parodyti, kad tik patenkinus žemesnio lygmens poreikį, ima dominuoti aukštesnio lygmens poreikis, tad poreikis tol, kol nėra patenkintas, yra individo motyvacijos šaltinis. U. Abulof'as (2017) atkreipé dèmesi ¡̣ tai, kad pirmieji keturi A. Maslow’o poreikiai yra tie patys, kaip ir kitu gyvūnų, unikalus, t. y. žmogiškas, yra tik savirealizacijos poreikis, tačiau tik patenkinus pagrindinius poreikius, pereinama prie aukštesnių hierarchijos lygmenų poreikių (Maheran, Junaidah, 2014).

Žvelgiant iš organizacinès perspektyvos, A. Maslow'o (2013) teorija susieja atlyginimą, naudą, organizacinę kultūrą, vadovavimą ir pan. ị vieną visumą. Fiziologinius poreikius patenkina darbuotojui skiriamas darbo užmokestis. Saugumo poreikiai apima darbo saugumą ir apibrèžtas pareigas arba struktūrą. Socialinius poreikius gali patenkinti teigiama organizacinè kultūra, leidžianti darbuotojams užmegzti tarpusavio ryšius. Pagarbos poreikiai tenkinami puoselèjant teigiamus 
valdymo santykius su darbuotojais, kai jie jaučiasi pasitikintys savimi, galintys tinkamai atlikti savo darbą. Savirealizacijos poreikius patenkinti sunkiau, jie įtraukia vadovybę, motyvuotus darbuotojus ị darbą, kuris atitinka jų galimybes. Pavyzdys gali būti motyvuoto darbuotojo perkèlimas ị aukštesnes pareigas.

Organizacijos saugumo poreikius gali patenkinti, kurdamos saugią organizacinę kultūrą, kaip pagarba ir atvirumu pagrịstą aplinką visiems darbuotojams. Nors teigiama, kad poreikių tenkinimą ir su tuo susijusią motyvaciją lemia tiek aplinka, tiek socialiniai aspektai (Gagne, Deci, 2005), dauguma mokslinių tyrimų atskleidžia organizacinị (pvz., organizacinę paramą) ir su darbu susijusị (pvz., darbiniai poreikiai) vaidmenị (Van den Broeck, Ferris, Chang, Rosen, 2016). Diskusijose mokslininkai daug dėmesio skiria lyderio darbuotojų palaikymui (pvz., vadovavimo stiliams), nors kai kurie moksliniai tyrimai atskleidžia, kad tenkinant darbuotojų poreikius svarbų vaidmenį gali vaidinti ir jų kolegos (Moreau, Mageau, 2012). Socialiniai poreikiai apima siekị megzti ryšius su kolegomis ir lyderiais, kurie būtų pagrịsti rūpinimusi vieni kitais ir veiksminga sąveika (Deci, Ryan, 2000), jausti tarpusavio ryšị, rūpestị vieni kitais, globą. Šị poreikị patenkins ir malonus bendravimas su bendradarbiais bei vadovais (Jungert, Van den Broeck, Schreurs, Osterman, 2018).

Organizacijos gali patenkinti pagarbos poreikius siūlydamos prisiimti didesnę atsakomybę darbe, atlikti sudètingas užduotis, sudarydamos asmeninio, profesinio augimo ir tobulèjimo galimybes, rengdamos geriausio darbuotojo ar panašius konkursus, apdovanodamos už gerą darbą.

Darbuotojai šiuos poreikius suvokia skirtingai, be to, laikui bėgant jie keičiasi: patenkinus vienus, kyla poreikis aukštesnio lygmens siekiams (Bhattacharya, Mittal, 2021).

Nesunku suprasti, kad ne iki galo patenkinti vieno lygmens poreikiai neigiamai paveiks ir kitų lygmenų poreikių tenkinimą, kas gali paskatinti gynybini darbuotojų atsaką (Stewart, Nodoushani, Stumpf, 2018). Atsisakius patenkinti pagrindinius darbuotojo poreikius, tokius kaip įvertinimas, pripažinimas, sąžiningumas, saugumas, kyla konfliktinių situacijų.

\section{Tyrimo metodologija}

Tyrimo duomenys buvo renkami anketinès apklausos metodu. Respondentams pateiktas uždarojo tipo klausimynas, siekiant nustatyti, kaip poreikiai tenkinami, remiantis A. Maslow'o poreikių hierarchijos teorija. Apklausos anketą sudaro demografinių klausimų blokas (organizacijos veiklos pobūdis, dydis, geografinis organizacijos padalinių išsidèstymas ir demografinès respondentų charakteristikos) ir pagrindinè dalis. Pastaroji suskirstyta remiantis A. Maslow'u ị penkias poreikių 
Sonata Staniulienè, Inga Kurienè

grupes, kiekvienoje jų pateikiant tris galimus teiginius. Vertindami juos darbuotojai rinkosi vieną iš trijų galimų atsakymų variantų: $0-n e, 1-i s ̌$ dalies, 2 - taip.

Klausimyno patikimumui ir skalès vidiniam nuoseklumui įvertinti apskaičiuotas Cronbach'o alfa (angl. Cronbach's alpha) koeficientas $(0,637)$ (1 lentelè), kuris remiasi paskirų klausimyno klausimų koreliacija ir įvertina, ar visi skalès klausimai pakankamai atskleidžia tiriamaji dydį bei ịgalina patikslinti reikiamų klausimų skaičių skalejje. Šis kriterijus atskleidè, kad klausimyno vidinis nuoseklumas yra priimtinas. Spearman-Brown'o didesnio patikimumo koeficiento reikšmė artima Cronbach'o alfa koeficiento reikšmei, kas reiškia, kad atsakymų i paskirus klausimus dispersijos yra panašios.

1 lentelè. Klausimyno skalès vidinio nuoseklumo pagrindimas

\begin{tabular}{|lll|}
\hline Cronbach'o alfa & Spearman-Brown'o koeficientas & vnt. \\
\hline 0,637 & 0,655 & 5 \\
\hline
\end{tabular}

Tyrimas atliktas apklausiant 84 dydžio, sektorių ir veiklų aspektais skirtingų Lietuvos organizacijų darbuotojus. Didžioji dalis apklaustujų (34\%) - paslaugas teikiančių įmonių darbuotojai, nemaža dalis (26\%) - prekybos įmonių, $10 \%$ gamybos organizacijų, likusi dalis $(30 \%)$ - įmonių, kurios užsiima mišria veikla. Pagal organizacijos dydi respondentai išsidèsto intervale nuo 1 iki 19 darbuotojų; iki 150 ir daugiau darbuotojų; daugiausia apklausta įmonių, turinčių 150 ir daugiau darbuotojų.

Tyrimo duomenys apdoroti ir analizuoti taikant SPSS programinę įrangą. Apskaičiuoti ir analizuoti reikšmių vidurkiai, medianos, modos, standartinis nuokrypis, asimetriškumas, imties intervalas. Duomenys palyginti juos kryžminant, darbuotojų poreikių tenkinimas Lietuvos organizacijose analizuotas vyraujančios organizacijoje darbuotojų lyties, organizacijos dydžio, geografinio organizacijos išsidèstymo aspektais. Taikant Pearson'o koreliacijos koeficientą tikrinta, kaip koreliuoja darbuotojų skirtingų poreikių tenkinimas ir darbuotojų bei organizacijų charakteristikos.

\section{Darbuotoju poreikiu Lietuvos organizacijose vertinimas}

Remiantis A. Maslow’o poreikių teorija, išanalizavus apklaustas organizacijas, gautas rezultatas rodo, kad dažniausia Lietuvos organizacijose užtikrinamas fiziologinių ir socialinių poreikių tenkinimas (iš 84 apklaustųjų ši atsakymą pasirinko 60), antroje vietoje lieka saugumo poreikiai (iš 84 atsakiusių organizacijų ši atsakymą pasirinko 59), trečioje vietoje pagal populiarumą - pagarbos poreikiai (iš 84 šį atsakymą pasirinko 53), mažiausiai tenkinami savirealizacijos poreikiai (iš 84 ši atsakymą pasirinko 45) (žr. 1 pav.). 


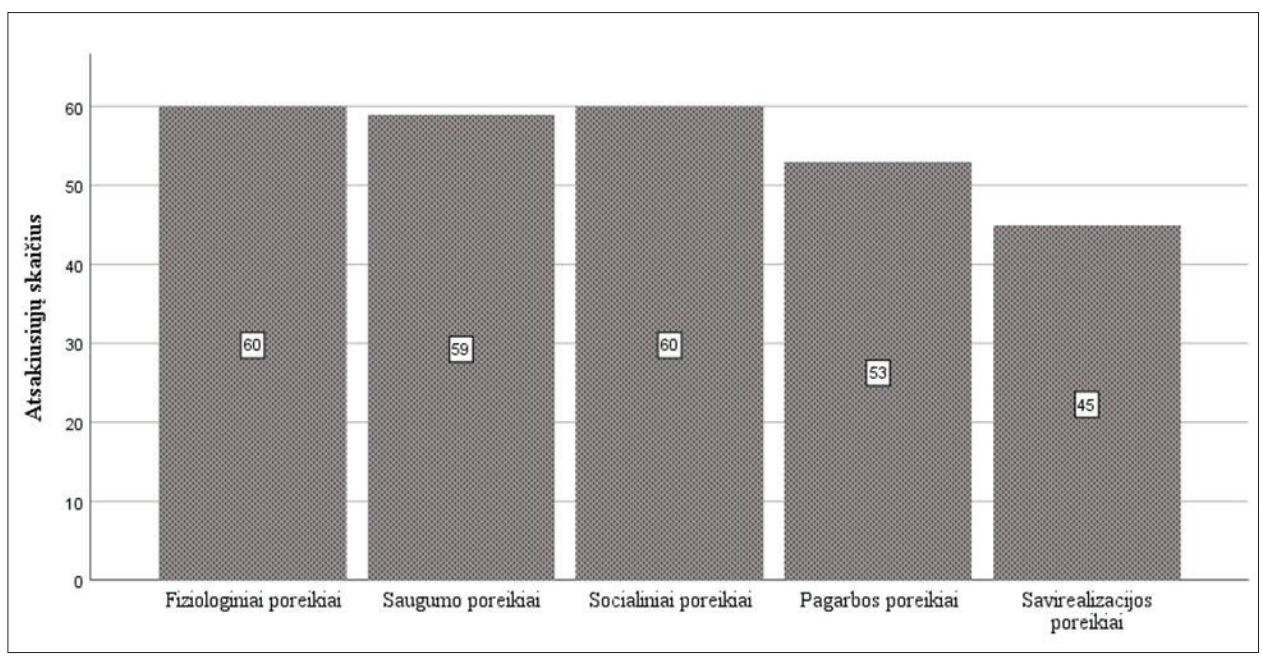

1 pav. Darbuotojų poreikių tenkinimas Lietuvos organizacijose

Analizuojant surinktus statistinius duomenis (žr. 2 lentelę) matyti, kad respondentų pateiktų atsakymų dèl jų poreikių tenkinimo vidurkis svyruoja nuo 1,65 (socialiniai poreikiai) iki 1,4 (savirealizacijos poreikiai) iš skalèje nuo 0 iki 2. Modos reikšmès atskleidžia, kad dažniausia respondentai rinkosi atsakymą taip, medianos - jog daugiausia pateikta atsakymų iš dalies ir taip ị visus užduotus klausimus dèl darbuotojų poreikių tenkinimo. Standartinis nuokrypis intervale nuo 0,585 iki 0,713 atskleidžia duomenų sklaidą apie vidurkį, kuri gana nedidelè, taigi skirtingų respondentų darbuotojų poreikių tenkinimas darbuotojų vertinamas panašiai. Asimetrijos koeficientu išmatavus, matyti neigiama (kairioji) duomenų asimetrija, kuri reiškia, kad darbuotojai labiau teigiamai nei neigiamai vertino savo poreikių tenkinimą dirbant Lietuvos organizacijose, visgi mažesnis pozityvumas išryškèjo pagarbos ir savirealizacijos poreikių tenkinimo atvejais.

2 lentelè. Darbuotojų poreikių tenkinimo pagrindinès charakteristikos

\begin{tabular}{|c|c|c|c|c|c|c|}
\hline & $\begin{array}{l}\text { Fiziologiniai } \\
\text { poreikiai }\end{array}$ & $\begin{array}{l}\text { Saugumo } \\
\text { poreikiai }\end{array}$ & $\begin{array}{l}\text { Socialiniai } \\
\text { poreikiai }\end{array}$ & $\begin{array}{l}\text { Pagarbos } \\
\text { poreikiai }\end{array}$ & $\begin{array}{l}\text { Savirealizaci- } \\
\text { jos poreikiai }\end{array}$ \\
\hline \multirow[t]{2}{*}{ Vnt. } & atsakyta & 84 & 84 & 84 & 84 & 84 \\
\hline & neatsakyta & 0 & 0 & 0 & 0 & 0 \\
\hline \multicolumn{2}{|c|}{ Vidurkis } & 1,62 & 1,64 & 1,65 & 1,58 & 1,40 \\
\hline \multicolumn{2}{|c|}{ Mediana } & 2,00 & 2,00 & 2,00 & 2,00 & 2,00 \\
\hline \multicolumn{2}{|c|}{ Moda } & 2,00 & 2,00 & 2,00 & 2,00 & 2,00 \\
\hline \multicolumn{2}{|c|}{ St. nuokrypis } & ,657 & ,594 & ,591 &, 585 &, 713 \\
\hline \multicolumn{2}{|c|}{ Asimetrija } & $-1,500$ & $-1,460$ & $-1,526$ & $-1,072$ &,- 777 \\
\hline \multicolumn{2}{|c|}{ St. asim. paklaida } &, 263 & ,263 & ,263 & ,263 &, 263 \\
\hline
\end{tabular}


Sonata Staniulienè, Inga Kurienè

Apibendrinant galima teigti, kad apskritai darbuotojų poreikiai tenkinami daugelyje Lietuvos organizacijų. Pirmieji trys poreikiai hierarchijos požiūriu (fiziologiniai, saugumo ir socialiniai) tenkinami daugiau kaip 70 \% (žr. 3 lentelę), tuo tarpu pagarbos $(56,7 \%)$ ir savirealizacijos $(48,5 \%)$ poreikių - tik maždaug pusė atvejų.

Lyginant gautus tyrimo duomenis darbuotojų lyties aspektu nustatyta, kad fiziologiniai poreikiai labiau tenkinami organizacijose, kuriose daugiausia dirba moterų $(48,5 \%)$, daugiausia vyrų turinčios įmonès jų fiziologinius poreikius tenkina $24,2 \%$, bendras rezultatas $-72,7 \%$ patenkintų fiziologinių poreikių nuo bendro atsakymų skaičiaus. Kad Lietuvos organizacijose tenkinami darbuotojų saugumo poreikiai, patvirtino net $70,1 \%$ respondentu. Tiek moterų, tiek vyrų atsakymai pasiskirstę panašiai (atitinkamai 37,3\% ir 32,8 \%). Socialiniai poreikiai tenkinami $70,1 \%$ : organizacijose, kuriose dirba daugiau moteru jie tenkinami geriau nei tose, kur vyrauja vyrai (atitinkamai 40,3\% ir 29,9\%). Remiantis pagarbos poreikio tenkinimo vertinimu $(56,7 \%)$, vyrų ir moterų atsakymai pasiskirste atitinkamai $31,3 \%$ ir 25,4 \%. Prasčiausiai Lietuvos organizacijose tenkinami darbuotojų savirealizacijos poreikiai (48,5\%). Tiek daugiau vyrų, tiek moterų turinčiose organizacijose jie tenkinamai vienodai prastai (atitinkamai 24,2 \% ir 24,2\%).

3 lentele. Darbuotojų poreikių tenkinimas organizacijoje vyraujančios lyties aspektu

\begin{tabular}{|c|c|c|c|c|c|c|}
\hline \multirow{4}{*}{$\begin{array}{l}\text { Fizio- } \\
\text { loginiai } \\
\text { poreikiai }\end{array}$} & \multirow{3}{*}{$\begin{array}{l}\text { Mote- } \\
\text { rys }\end{array}$} & & \multirow{2}{*}{\begin{tabular}{|l|} 
Ne \\
1
\end{tabular}} & \multirow{2}{*}{$\begin{array}{l}\text { Iš dalies } \\
8\end{array}$} & \multirow{2}{*}{$\begin{array}{l}\text { Taip } \\
32\end{array}$} & \multirow{2}{*}{\begin{tabular}{|l|} 
Iš viso \\
41
\end{tabular}} \\
\hline & & Atsakymų skaičius & & & & \\
\hline & & $\%$ nuo visų atsakiusiujų & $1,5 \%$ & $12,1 \%$ & $48,5 \%$ & $62,1 \%$ \\
\hline & Vyrai & Atsakymų skaičius & 4 & 5 & 16 & 25 \\
\hline & & $\%$ nuo visų atsakiusiujų & $6,1 \%$ & $7,6 \%$ & $24,2 \%$ & $37,9 \%$ \\
\hline \multirow{2}{*}{\multicolumn{2}{|c|}{ Iš viso }} & Atsakymų skaičius & 5 & 13 & 48 & 66 \\
\hline & & $\begin{array}{l}\text { \% nuo bendro atsakymų } \\
\text { skaičiaus }\end{array}$ & $7,6 \%$ & $19,7 \%$ & $72,7 \%$ & $100,0 \%$ \\
\hline \multirow{4}{*}{$\begin{array}{l}\text { Saugumo } \\
\text { poreikiai }\end{array}$} & \multirow{2}{*}{$\begin{array}{l}\text { Mote- } \\
\text { rys }\end{array}$} & Atsakymų skaičius & 1 & 15 & 25 & 41 \\
\hline & & $\%$ nuo visų atsakiusiujų & $1,5 \%$ & $22,4 \%$ & $37,3 \%$ & $61,2 \%$ \\
\hline & \multirow[t]{2}{*}{ Vyrai } & Atsakymų skaičius & 2 & 2 & 22 & 26 \\
\hline & & \% nuo visų atsakiusiųjų & $3,0 \%$ & $3,0 \%$ & $32,8 \%$ & $38,8 \%$ \\
\hline \multirow{2}{*}{\multicolumn{2}{|c|}{ Iš viso }} & Atsakymų skaičius & 3 & 17 & 47 & 67 \\
\hline & & $\begin{array}{l}\text { \% nuo bendro atsakymų } \\
\text { skaičiaus }\end{array}$ & $4,5 \%$ & $25,4 \%$ & $70,1 \%$ & $100,0 \%$ \\
\hline \multirow{4}{*}{$\begin{array}{l}\text { Soci- } \\
\text { aliniai } \\
\text { poreikiai }\end{array}$} & \multirow{4}{*}{$\begin{array}{l}\text { Mote- } \\
\text { rys } \\
\text { Vyrai }\end{array}$} & Atsakymų skaičius & 3 & 11 & 27 & 41 \\
\hline & & \% nuo visų atsakiusiųjų & $4,5 \%$ & $16,4 \%$ & $40,3 \%$ & $61,2 \%$ \\
\hline & & Atsakymų skaičius & 2 & 4 & 20 & 26 \\
\hline & & $\%$ nuo visų atsakiusiujų & $3,0 \%$ & $6,0 \%$ & $29,9 \%$ & $38,8 \%$ \\
\hline \multirow{2}{*}{\multicolumn{2}{|c|}{ Iš viso }} & Atsakymų skaičius & 5 & 15 & 47 & 67 \\
\hline & & $\begin{array}{l}\% \text { nuo bendro atsakymų } \\
\text { skaičiaus }\end{array}$ & $7,5 \%$ & $22,4 \%$ & $70,1 \%$ & $100,0 \%$ \\
\hline
\end{tabular}




\begin{tabular}{|c|c|c|c|c|c|c|}
\hline \multirow{3}{*}{$\begin{array}{l}\text { Pagarbos } \\
\text { poreikiai }\end{array}$} & \multirow{3}{*}{$\begin{array}{l}\text { Mote- } \\
\text { rys }\end{array}$} & & \multirow{2}{*}{$\begin{array}{l}\text { Ne } \\
2\end{array}$} & \multirow{2}{*}{$\frac{\text { Iš dalies }}{18}$} & \multirow{2}{*}{$\frac{\text { Taip }}{21}$} & \multirow{2}{*}{$\begin{array}{l}\text { Ǐs viso } \\
41\end{array}$} \\
\hline & & Atsakymų skaičius & & & & \\
\hline & & \% nuo visų atsakiusiųjų & $3,0 \%$ & $26,9 \%$ & $31,3 \%$ & $61,2 \%$ \\
\hline & Vyrai & Atsakymų skaičius & 1 & 8 & 17 & 26 \\
\hline & & \% nuo visų atsakiusiųjų & $1,5 \%$ & $11,9 \%$ & $25,4 \%$ & $38,8 \%$ \\
\hline \multirow{2}{*}{\multicolumn{2}{|c|}{ Iš viso }} & Atsakymų skaičius & 3 & 26 & 38 & 67 \\
\hline & & \% nuo visų atsakiusiųjų & $4,5 \%$ & $38,8 \%$ & $56,7 \%$ & $100,0 \%$ \\
\hline \multirow{4}{*}{$\begin{array}{l}\text { Savirea- } \\
\text { lizacijos } \\
\text { poreikiai }\end{array}$} & \multirow{2}{*}{$\begin{array}{l}\text { Mote- } \\
\text { rys }\end{array}$} & Atsakymų skaičius & 6 & 19 & 16 & 41 \\
\hline & & \% nuo visų atsakiusiųjų & $9,1 \%$ & $28,8 \%$ & $24,2 \%$ & $62,1 \%$ \\
\hline & \multirow[t]{2}{*}{ Vyrai } & Atsakymų skaičius & 4 & 5 & 16 & 25 \\
\hline & & \% nuo visų atsakiusiųjų & $6,1 \%$ & $7,6 \%$ & $24,2 \%$ & $37,9 \%$ \\
\hline \multirow{2}{*}{\multicolumn{2}{|c|}{ Iš viso }} & Atsakymų skaičius & 10 & 24 & 32 & 66 \\
\hline & & \% nuo visų atsakiusiųjų & $15,2 \%$ & $36,4 \%$ & $48,5 \%$ & $100,0 \%$ \\
\hline
\end{tabular}

Vertinant poreikių tenkinimą tyrime dalyvavusių ịmonių geografinio išdèstymo aspektu, galima teigti, kad tiek Lietuvoje, tiek užsienyje savo filialus turinčios organizacijos darbuotojų poreikių tenkinimui skiria didelį dèmesị. Kaip matome iš 4 lentelès, daugiausia dėmesio Lietuvoje veikiančios organizacijos skiria darbuotojų socialiniams poreikiams tenkinti (41,7 \%). Tuo tarpu Lietuvoje ir užsienyje savo filialus turinčios ịmonès geriau tenkina darbuotojų fiziologinius poreikius $(31,0 \%)$.

4 lentele. Darbuotojų poreikių tenkinimas organizacijose geografinio išsidèstymo aspektu

\begin{tabular}{|c|c|c|c|c|c|}
\hline & & Lietuvoje & $\begin{array}{l}\text { Lietuvoje ir } \\
\text { užsienyje }\end{array}$ & Užsienyje & Iš viso \\
\hline \multirow[t]{3}{*}{ Fiziologiniai poreikiai } & $\mathrm{Ne}$ & $6,0 \%$ & $2,4 \%$ & $1,2 \%$ & $9,5 \%$ \\
\hline & Iš dalies & $15,5 \%$ & $3,6 \%$ & $0,0 \%$ & $19,0 \%$ \\
\hline & Taip & $38,1 \%$ & $31,0 \%$ & $2,4 \%$ & $71,4 \%$ \\
\hline \multicolumn{2}{|l|}{ Iš viso } & & & & $100,0 \%$ \\
\hline \multirow[t]{3}{*}{ Saugumo poreikiai } & $\mathrm{Ne}$ & $3,6 \%$ & $1,2 \%$ & $1,2 \%$ & $6,0 \%$ \\
\hline & Iš dalies & $15,5 \%$ & $7,1 \%$ & $1,2 \%$ & $23,8 \%$ \\
\hline & Taip & $40,5 \%$ & $28,6 \%$ & $1,2 \%$ & $70,2 \%$ \\
\hline \multicolumn{2}{|l|}{ Iš viso } & & & & $100,0 \%$ \\
\hline \multirow[t]{3}{*}{ Socialiniai poreikiai } & $\mathrm{Ne}$ & $3,6 \%$ & $1,2 \%$ & $1,2 \%$ & $6,0 \%$ \\
\hline & Iš dalies & $14,3 \%$ & $7,1 \%$ & $1,2 \%$ & $22,6 \%$ \\
\hline & Taip & $41,7 \%$ & $28,6 \%$ & $1,2 \%$ & $71,4 \%$ \\
\hline \multicolumn{2}{|l|}{ Iš viso } & & & & $100,0 \%$ \\
\hline \multirow[t]{3}{*}{ Pagarbos poreikiai } & $\mathrm{Ne}$ & $4,8 \%$ & $0,0 \%$ & $0,0 \%$ & $4,8 \%$ \\
\hline & Iš dalies & $17,9 \%$ & $11,9 \%$ & $2,4 \%$ & $32,1 \%$ \\
\hline & Taip & $36,9 \%$ & $25,0 \%$ & $1,2 \%$ & $63,1 \%$ \\
\hline \multicolumn{2}{|l|}{ Iš viso } & & & & $100,0 \%$ \\
\hline \multirow{3}{*}{$\begin{array}{l}\text { Savirealizacijos po- } \\
\text { reikiai }\end{array}$} & $\mathrm{Ne}$ & $10,7 \%$ & $2,4 \%$ & $0,0 \%$ & $13,1 \%$ \\
\hline & Iš dalies & $15,5 \%$ & $16,7 \%$ & $1,2 \%$ & $33,3 \%$ \\
\hline & Taip & $33,3 \%$ & $17,9 \%$ & $2,4 \%$ & $53,6 \%$ \\
\hline \multicolumn{2}{|l|}{ Iš viso } & & & & $100,0 \%$ \\
\hline
\end{tabular}


Sonata Staniulienè, Inga Kurienè

Pearson'o koreliacinio koeficiento analizè (žr. 5 lentelę) atitinka A. Maslow'o poreikių hierarchijos teoriją, kuri teigia, kad pirmiausia būtina patenkinti žemesnès poreikių hierarchijos pakopos poreikius: pastebimas ryšys tarp fiziologinių ir kitų poreikių silpnèja kopiant poreikių hierarchijos laiptais aukštyn: fiziologinių poreikių tenkinimas siejasi su saugumo poreikiais $r=0,419$, o su socialiniais poreikiais jau tik $r=0,123$, pagarbos $-r=0,84$, tuo tarpu sąsajos su savirealizacijos poreikiais jau pasižymi silpnu neigiamu ryšiu $-r=-0,156$. Reikšmingas ir vidutiniškai stiprus koreliacinis ryšys stebimas tik tarp gretimų pagal poreikių hierarchiją pakopų: fiziologinių ir saugumo poreikių $(r=0,419$, kai $p<0,000)$, saugumo ir socialiniu poreikiu $(r=0,468$, kai $p<0,000)$, socialinių ir pagarbos poreikių $(r=0,450$, kai $p<0,000)$, pagarbos ir savirealizacijos poreikių $(r=0,496$, kai $p<0,000)$.

5 lentelè. Pearson'o koreliacijos ryšys tarp skirtingų poreikių tenkinimo grupių

\begin{tabular}{|c|c|c|c|c|c|c|}
\hline & & $\begin{array}{l}\text { Fizio- } \\
\text { loginiai } \\
\text { poreikiai }\end{array}$ & $\begin{array}{l}\text { Sau- } \\
\text { gumo } \\
\text { porei- } \\
\text { kiai }\end{array}$ & $\begin{array}{l}\text { Socia- } \\
\text { liniai } \\
\text { porei- } \\
\text { kiai }\end{array}$ & $\begin{array}{l}\text { Pagar- } \\
\text { bos } \\
\text { porei- } \\
\text { kiai }\end{array}$ & $\begin{array}{l}\text { Savirea- } \\
\text { lizacijos } \\
\text { poreikiai }\end{array}$ \\
\hline \multirow{2}{*}{$\begin{array}{l}\text { Fiziologiniai } \\
\text { poreikiai }\end{array}$} & Pearson'o koeficientas & 1 & ,419** & ,123 & ,084 &,- 156 \\
\hline & Sig. (2-tailed) & &, 000 & ,266 &, 450 &, 158 \\
\hline $\begin{array}{l}\text { Saugumo } \\
\text { poreikiai }\end{array}$ & $\begin{array}{l}\text { Pearson'o koeficientas } \\
\text { Sig. (2-tailed) }\end{array}$ & $\begin{array}{l}, 419^{* *} \\
, 000\end{array}$ & 1 & $\begin{array}{l}\mathbf{4 6 8} 8^{* *} \\
, 000\end{array}$ & $\begin{array}{l}\mathbf{4 6 8} 8^{* *} \\
, 000\end{array}$ & $\begin{array}{l}\mathbf{1 7 5} \\
, 112\end{array}$ \\
\hline \multirow{2}{*}{$\begin{array}{l}\text { Socialiniai } \\
\text { poreikiai }\end{array}$} & Pearson'o koeficientas &, 123 &, $468^{* *}$ & 1 & ,450 $0^{* *}$ &, $307^{* *}$ \\
\hline & Sig. (2-tailed) & ,266 &, 000 & &, 000 &, 005 \\
\hline \multirow{2}{*}{$\begin{array}{l}\text { Pagarbos } \\
\text { poreikiai }\end{array}$} & Pearson'o koeficientas & ,084 & $468^{* *}$ &, $450^{* *}$ & 1 &, $496^{* *}$ \\
\hline & Sig. (2-tailed) & 450 &, 000 &, 000 & &, 000 \\
\hline \multirow{2}{*}{$\begin{array}{l}\text { Savirealizaci- } \\
\text { jos poreikiai }\end{array}$} & Pearson'o koeficientas &,- 156 &, 175 &, $307^{* *}$ &, $496^{* *}$ & 1 \\
\hline & Sig. (2-tailed) &, 158 &, 112 &, 005 &, 000 & \\
\hline
\end{tabular}

* - koreliacijos koeficientas statistiškai reikšmingas, kai $p<0,05$.

Nustatytas silpnas koreliacinis ryšys tarp savirealizacijos poreikių patenkinimo ir organizacijos dydžio $(r=0,203$, kai $p<0,068)$; reikšmingo koreliacinio ryšio su kitais poreikiais, organizaciju geografiniu išsidèstymu bei demografine sudètimi nenustatyta.

\section{Išvados}

Mokslinejje literatūroje vis dar gausu tyrimų, kuriuose A. Maslow’o poreikių hierarchijos teorija remiamasi kaip pagrindu, nagrinejjant darbuotojų elgseną nuolat kintančiomis organizacijų veiklos ir darbo rinkos sąlygomis. 


\section{DARBUOTOJŲ POREIKIŲ TENKINIMAS LIETUVOS ORGANIZACIJOSE}

Iš esmès tyrimo rezultatai Lietuvos organizacijose atitinka A. Maslow'o poreikių hierarchijos teoriją, kuri teigia, kad pirmiausia būtina patenkinti žemesnès poreikių hierarchijos pakopos poreikius, kad būtų sudarytos sąlygos patenkinti kito lygmens poreikius.

Galima teigti, kad dauguma Lietuvos organizacijų tenkina darbuotojų fiziologinius, saugumo ir socialinius poreikius, tačiau dar beveik pusès organizacijų darbuotojai nesijaučia pakankamai gerbiami, dar mažiau Lietuvos organizacijų darbuotojų turi galimybę save realizuoti darbe, tačiau, remiantis paties A. Maslow'o nuomone, kad save realizuoti pavyks tik išrinktiesiems, šiuo laikmečiu ir makroaplinkoje galima konstatuoti aukštą organizacinio potencialo pasiekimų lygị.

\section{Literatūra}

Abulof, U. (2017). Be Yourself! How Am I Not myself? II. Society and Politics: Between Essentialist and Existentialist Authenticity. Symposium: Revisiting Maslow: Human Needs in the 21st Century. Society, Vol. 54, p. 530-532. Doi: 10.1007/s12115-017-0183-0.

Baard, P. P., Deci, E. L., Ryan, R. M. (2004). Intrinsic need satisfaction: A motivational basis of performance and well-being in two work settings. Journal of Applied Social Psychology, Vol. 34, p. 2045-2068.

Bhattacharya, S., Mittal, P. (2021). The Impact of Individual Needs on Employee Performance while Teleworking. Australasian Accounting Business \& Finance Journal, Vol. 15, No. 1, p. 65-85.

Broeck, A. van den, Ferris, D., Chang, C., Rosen, C. (2016). A review of self-determination theory's basic psychological needs at work. Journal of Management, Vol. 42, p. 1195-1229.

Broeck, A. van den, Vansteenkiste, M., Lens, W., De Witte, H. (2010). Unemployed individuals' work values and job flexibility: An explanation from expectancy-value theory and self-determination theory. Applied Psychology: An International Review, Vol. 59, p. 296-317.

Broek, A. van den, Vansteenkiste, M., Witte, H. de, Lens, W. (2008). Explaining the relationships between job characteristics, burnout and engagement: The role of basic psychological need satisfaction. Work \& Stress, Vol. 22, p. 277-294.

Cangemi, J. (2009). Analysis of an adversarial labor/management situation in a Latin American industrial setting: A case study using Maslow's Hierarchy of Needs. Organization Development Journal, Vol. 27(1), p. 37-47.

Deci, E. L., Ryan, R. M. (2000). The "what" and "why" of goal pursuits: Human needs and the self-determination of behaviour. Psychological Inquiry, Vol. 11, p. 227-268.

Fife, E., Pereira, F. (2008). Maslow's Hierarchy of Needs and ICT: Challenges of end-user adoption of digital life. The Journal (Institute of Telecommunications Professionals), Vol. 2(4), p. 23-28.

Gagne, M., Deci, L. E. (2005). Self-Determination Theory and Work Motivation. Journal of Organizational Behavior, Vol. 26, p. 331-362.

Gagne, M., Vansteenkiste, M. (2013). Self-determination theory's contribution to positive organizational psychology. In A.B. Bakker (Ed.), Advances in Positive Organizational Psychology, Vol. 1, p. 61-82. Bingley: Emerald Group Publishing.

Hing Po Lam, V. (2020). Evaluation of Implementation of Maslows Hierarchy of Needs to Fulfil the Needs of Freelance Journalist and Adaptation of Psychological Contract into Employment Relationship in Hong Kong. The International Journal of Social Sciences and Humanities Invention, Vol. 7(07), p. 6076-6079. Doi: $10.18535 /$ ijsshi/v7i07.06.

Jungert, T., Van den Broeck, A., Schreurs, B., Osterman, U. (2018). How Colleagues Can Support Each Other's Needs and Motivation: An Intervention on Employee Work Motivation. Applied Psychology: An International Review, Vol. 67 (1), p. 3-29. Doi: 10.1111/apps.12110.

Lester, D. (2013). Measuring Maslow's hierarchy of needs. Psychological Reports: Mental \& Physical Health, Vol. 113 (1), p. 15-17.

Maheran, Z., Junaidah, H. M. (2014). The Effects of Maslow's Hierarchy of Needs on Zakah Distribution Efficiency in Asnaf Assistance Business Programme. Malaysian Accounting Review, Vol. 13, No. 1, p. $27-44$. 
Sonata Staniulienè, Inga Kurienè

Mahyudin, A. B., Abdullah, A. G. (2011). Towards achieving the quality of life in the management of zakat distribution to the rightful recipients (the poor and needy). International Journal of Business and Social Sciences, Vol. 2 (4), p. 237-245. ISSN 2219-1933.

Maslow, A. H. (1954). Motivation and personality. New York: Harper \& Row.

Moreau, E., Mageau, G. (2012). The importance of perceived autonomy support for the psychological health and work satisfaction of health professionals: Not only supervisors count, colleagues too! Motivation and Emotion, Vol. 36, p. 268-286.

O’Connor, D., Yballe, L. (2007). Maslow revisited: Constructing a road map of human nature. Journal of Management Education, Vol. 31(6), p. 738-756.

Ozsoy, E. (2019). An Empirical Test of Herzberg's Two-Factor Motivation Theory. Marketing and Management of Innovations, Vol. 1, p. 11-20. Prieiga internete: http://doi.org/10.21272/mmi.2019.1-01.

Perkins, J. (2004). Confessions of an Economic Hit Man. New York: Plume.

Ryan, B. J., Coppola, D., Canyon, D. V., Brickhouse, M., Swienton, R. (2020). COVID-19 Community Stabilization and Sustainability Framework: An Integration of the Maslow Hierarchy of Needs and Social Determinants of Health. Disaster Medicine and Public Health Preparedness, April, p. 623-629. Doi: 10.1017/dmp.2020.109.

Šerikova, A., Matuzienė, I. (2006). Darbuotojų poreikių stiprumo įvertinimas Šiaulių miesto privataus sektoriaus organizacijose. Socialiniai tyrimai, Nr. 2 (8), p. 132-140.

Soni, B., Soni, R. (2016). Enhancing Maslow's Hierarchy of Needs for Effective Leadership. Competition Forum, Vol. 14, Issue 2, p. 259-263.

Stewart, C., Nodoushani, O., Stumpf, J. (2018). Cultivating Employees Using Maslow's Hierarchy of Needs. Competition Forum, Vol. 16, Issue 2, p. 67-75.

Trethewey, A. Goodall, H. L. (2007). Leadership Reconsidered as Historical Subject: Sketches from the Cold War to Post-9/11. Leadership, Vol. 3(4), p. 457-477.

Vveinhardt, J., Gulbovaite, E. (2013). Poreikių hierarchijos koncepcinis pagrisstumas nacionaliniame vertybių kongruencijos kontekste. Socialiniai tyrimai, Nr. 4 (2), p. 143-162.

Zakaria, M., Ahmad, J., Malek, N. A. B. (2014). The Effects of Maslow's Hierarchy of Needs on Zakah Distribution Efficiency in Asnaf Assistance Business Program. Malaysian Accounting Review, Vol. 13, No. 1, p. $27-44$.

\section{MEETING THE NEEDS OF EMPLOYEES IN THE CASE OF LITHUANIAN ORGANISATIONS}

\section{Sonata Staniulienė, Inga Kurienė}

Summary

A. Maslow's theory of the hierarchy of needs is widely used by researchers as a basis for studying the needs of individuals. Motivation plays an important role in making people successful and happy in both their daily and their work life. Maintaining a high level of employee motivation is essential for making a positive contribution to employee well-being and the sustainability of organisations.

Several motivation theories have been developed to explain a set of motivations and needs in the field of motivation. The theory of the hierarchy of needs is widely accepted, and it has been particularly supported by many managers, because it is logical and simple, and therefore easy to understand. This theory explains what motivates people to work, and has shown managers that work motives are determined by a wide range of needs. 
Maslow's theory of the hierarchy of needs is the best-known and most focused theory of motivation based on the needs of individuals. Maslow hypothesised that people are motivated to act by a variety of needs, which are arranged according to a certain hierarchy, and can be divided into five levels: physiological, safety, social, self-esteem and self-realisation.

1. At the bottom of the hierarchy are basic needs, or physiological needs, such as food and water. Once humans satisfy the need for basic nutrition, they will attempt to accomplish more. Maslow believes that these needs are the most basic and instinctive needs in the hierarchy, because all needs are secondary until these physiological needs are met.

2. After fulfilling physiological needs, humans strive for safety and security. Security needs are important for survival, but they are not as demanding as physiological needs. These needs include the desire for steady employment, health insurance, safe neighbourhoods, and shelter from the environment.

3. Humans also need love, a sense of belonging and affection. Maslow considers these needs to be less basic than physiological and security needs. Relationships, such as friendship, romantic attachments and family, help fulfil these needs for companionship and acceptance, as does involvement in social, community and religious groups.

4. The need for self-esteem emerges after humans have fulfilled their social needs. This level of need will be achieved after they feel comfortable with what they have accomplished. This is also the success level or status of the self and others.

5. Self-realisation is the highest level of Maslow's hierarchy of needs. Those who achieve this level of needs are aware of and concerned with personal growth, and these attributes drive them to fulfil their potential. However, they are less concerned about the opinions of others.

Figure 1 depicts Maslow's hierarchy of needs.

Maslow articulates that quality of life will be achieved if needs and comfort are fulfilled. Furthermore, Maslow's theory is widely used by researchers as the underlying basis for examining the needs of human beings. Given these facts, it indicates that if humans are unable to fulfil their basic needs, their life will have no quality.

From an organisational point of view, Maslow's theory combines salaries, money, organisational culture, leadership, and so on, into one unified whole. Physiological needs are met by the employee's salary. Security needs include job security and definition responsibilities or structure. Social needs can be met by a positive organisational culture that allows employees to connect with each other, respecting the need for a positive management relationship with employees, under leadership that allows them to trust and ultimately do their job. It is more difficult to meet 
the needs of self-realisation: they involve management, and actively involve motivated employees in work that meets their capabilities. An example might be the motivated promotion of an employee to a complex position.

There is a wealth of research in scientific literature in which Maslow's theory of the hierarchy of needs is used as a foundation for examining employee behaviour in a constantly undefined trajectory, in changing and uniquely new organisational and labour market conditions.

In essence, the results of the study in Lithuanian organisations are in line with Maslow's theory of the hierarchy of needs, which states that the needs of the last level in the hierarchy of needs must be met first in order to create the conditions for the next needs. It can be said that most Lithuanian organisations are satisfied with the physiological, safety and social needs of employees, but almost half of the organisations do not feel sufficiently respected, and even fewer employees in Lithuanian organisations have opportunities to realise themselves in the work environment. However, compared to Maslow's own opinion that only the chosen ones will succeed in realising themselves, in this age and in the macro environment, one can point to a huge level of achievement in the development of organisational potential.

Sonata Staniulienè - docentè, daktare (socialiniai mokslai - vadyba), Vytauto Didžiojo universiteto Ekonomikos ir vadybos fakulteto Vadybos katedra

El paštas: sonata.staniuliene@,vdu.lt_ 